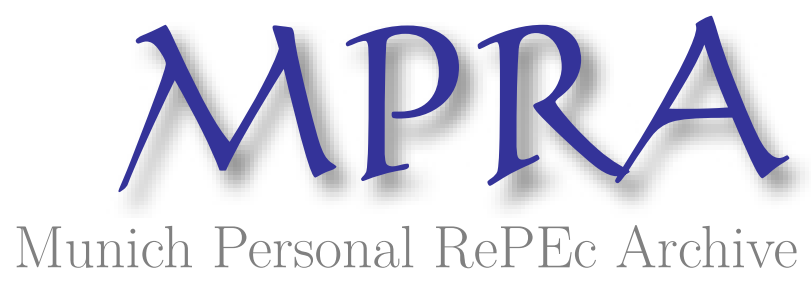

\title{
Improving Understanding of the Social Security OASDI Trust Fund
}

Schmult, Brian

24 December 2012

Online at https://mpra.ub.uni-muenchen.de/44227/

MPRA Paper No. 44227, posted 06 Feb 2013 01:56 UTC 


\title{
Improving Understanding of the Social Security OASDI Trust Fund
}

\author{
Brian Schmult \\ bcs@sgeo.com, 609-683-0449 \\ Working Paper WP-2012-1 \\ Revised February 5, 2013 \\ JEL: H55, H60
}

\begin{abstract}
This paper argues that the Social Security OASDI Trust Fund is widely misunderstood by the public, thereby corrupting the debate on how to handle future scheduled benefits, and increasing the risk of program changes that would not be accepted if people understood how the program functions. The Trust Fund is a fiscal nullity but appears to be regarded by many as essential, hence the public debate is about how to "fix" it, rather than about the moral question of whether to fund scheduled benefits, which are clearly affordable. This misunderstanding indicates the need for a shift in emphasis in public descriptions of the program. For this, this paper lays out a set of data, arguments and analogies that are asserted to be accurate representations of the OASDI program and Trust Fund operation, and which are proposed as tools for public education. Finally, this paper argues that an important step in shifting public debate is to re-institute full recourse to Treasury funding for any payroll tax shortfall, which will force the public debate back to benefit levels and revenue sources.
\end{abstract}




\section{Introduction}

The Social Security OASDI (Old-Age, Survivors and Disability Insurance) program has been the subject of much debate concerning the ability of society to afford it, with a majority of Americans believing it has serious problems [AARP 2010, Altman 2005, Helman 2011 and WP 2011]. Central to this debate has been the condition of the OASDI Trust Fund (hereafter, the "TF"). It is officially made a central issue by the annual issuance of the Trustees Report on the condition of the TF. Its primary purpose is reporting the TF status, and it emphasizes that when the TF is exhausted, only part of scheduled benefits will be paid, making TF importance explicit.

The debate over the relevance of the TF is well known. Supporters correctly argue that benefits will be paid out of the TF just like any other fund [Altman 2010], while others correctly point out that there are no income-producing assets in the TF [Bartlett 2011]. Both of these are true, leading to the Trust Fund Paradox: that it is not needed but benefits will still be paid (up to a point) even when there is a payroll tax shortfall. The answer to the paradox is that the TF actually is not fiscally needed: it is merely budget authority for the pay-as-you-go cash stream that is normal for most government benefits, and the cash stream is adequate. This cash stream is primarily the payroll tax, which Social Security Administration (SSA) has unlimited access to, and general Treasury funds to make up any shortfall, for which the SSA has only limited access to. The only relevance of the TF is to provide the legally necessary budget authority for access to Treasury funding, up to a limit (its notional balance). The bonds in the TF are merely chits: they have value to the OASDI program in that they can be exchanged for money from Treasury, but they are of no value in helping Treasury procure this money.

The ability to pay scheduled benefits is strictly a matter of collecting the necessary tax revenue; no revenue-producing assets exist that can help. Yet the general public almost certainly does not understand this, otherwise surveys would not show that it is worried about "bankruptcy" and that the system needs to be "fixed." This is a critical point for public debate, as arguments about TF "insolvency" can be used to press for changes that may not be agreed to if people understood how the program and the TF actually work. (To quote Baker, "As a result of a steady stream of misinformation, the public could possibly allow a program that it values immensely to be seriously undermined or dismantled." [Baker 1999])

The effect of the TF is to arbitrarily cap the collective benefit payment level to that of future current-period payroll tax revenue, regardless of scheduled benefits (i.e., those specified in the annual statements sent to OASDI participants). Thus the TF is not a fiscal device at all, but (combined with a future payroll tax rate) rather is a moral judgement: that, no matter what the statements say, beneficiaries do not deserve what they are scheduled. Effectively, a stealth claim is being made of "moral unaffordability" (we should not pay) by stating it as a claim of fiscal unaffordability (we can not pay). By mistaking a moral judgement for a fiscal problem, the public is permitting a moral question to be turned into a fiscal one, shielding the moral issue from proper scrutiny. Hence the position of this paper is that the TF should be ignored so that the entire debate on paying scheduled benefits can center on the moral issue of whether we should pay.

In general, no good decisions about an issue can be made unless those with a stake understand the issue. Good decisions are particularly unlikely if the concern revolves around issues that are not relevant ( $\mathrm{TF}$ solvency and bankruptcy) and skirts the one that is (how much tax). To this end, this paper expands on the argument that the public misunderstands the TF, and presents a number of arguments, analogies and data that are proposed to be accurate and useful as tools for public education. Note that this argument is about where the debate should be; the morality debate itself is not entered here, so issues of fairness (i.e., [Diamond 2004]) in the tax and benefit structure are not addressed.

In additional to not understanding the $\mathrm{TF}$, it is likely that the public also does not understand that the required taxes are affordable. (Affordability means that the program could easily be funded 
if desired, mostly a technical question. Being affordable is not the same as wanting to fund it, a political and moral question.) Given the likely public concept of what a trust fund is, a logical response to the idea of the TF running out would be simply "why not refill it?" Since the public perception is that the program is in serious trouble, it is a reasonable conclusion that the public's answer to this question is "because we cannot afford to." So, even though affordability should be obvious, a set of data and arguments for public use will be proposed here, so that the paper is a more complete package of education tools.

Section 2 briefly reviews relevant aspects of the OASDI program and the TF, for readers not familiar with the program. Section 3 presents arguments that the public misunderstands how the TF works. Section 4 proposes various analogies useful for public education on how the TF works. Affordability arguments are presented in Section 5.

\section{Review of Relevant Aspects of the OASDI Program and the Trust Fund}

The OASDI program is, and has been, a pay-as-you-go benefit program that is usually described as an insurance program (although the main program, Old Age, is not similar to any private insurance). There are two fundamental components of interest here, the benefit and revenue schedules. The schedule of benefits is set by law as a function of the beneficiary's earning history, without regard to OASDI funding at the time of payment. While benefits are proportional to earnings, there are two "bend points" in the curve, so lower income workers get a higher percentage of their pay replaced than higher income ones. The funding schedule, originally, and primarily, is a flat tax on a worker's W-2 income, up to a limit. From 1943 to 1950 the OASDI program had full recourse to Treasury for any shortfall from the payroll tax, but that has been removed [Altman 2005]. Presently, the Social Security Administration (SSA) has no authority to borrow or to increase tax rates on its own, so its ability to pay benefits is limited by its income, not determined by what it is scheduled to pay out. It is presumed that if income is lacking, and lacking a sudden change in the law, only partial benefits will be paid. So the issue regarding the revenue vs. the benefit schedules is what happens if scheduled benefits exceed payroll tax revenues at any time.

This problem is supposed to be solved by the TF. All revenue flows into the TF, and program expenses are paid out of the TF. This solves short-term mismatches between inflow and outflow by providing a buffer. In addition, the payroll tax was increased to a level higher than required for current benefits at the time. This excess revenue "accumulated" in the TF, but in reality, all excess payroll tax revenue was immediately spent by Treasury, with the promise to repay it in the future as it is needed, with interest. This "saving" is implemented with special government bonds, which cannot be sold to the public. When the OASDI program suffers a shortfall in the payroll tax (which commenced in 2010 and is predicted to continue to the horizon) it redeems bonds from the TF through Treasury. This of course must be done primarily through the income tax.

Hence all OASDI costs are covered on a pay-as-you-go basis through a combination of payroll and income taxes. The Social Security Trustees Report [SSA 2012b] states that the income tax share will rise to around $25 \%$ in the early 2030's and that thereafter, the payroll tax will continue to cover around $75 \%$ of scheduled benefits. The only catch is that this recourse to Treasury (the income tax) is limited by the amount of excess payroll taxes collected in the past (plus interest). Once this limit is reached, access to the income tax is cut off, and benefits become limited by current payroll tax revenue once again.

Note that the use of the TF and the past rise in payroll taxes above the level of costs has a nonobvious effect. It did not create any asset that can produce future value without recourse to the income tax. Rather, it merely transferred part of the funding for past general programs to the payroll tax, in exchange for a future (i.e., now) transfer of part of the funding of OASDI benefits to 
the income tax. In a sense this has smoothed the use of the regressive payroll tax over time, keeping it at a constant level over a longer period, while the income tax burden varies as necessary.

Also note that there is no net "hump" in costs due to the baby boom, so the past increase in payroll tax cannot serve to smooth this non-existent hump. See Table 1 column 4, the total OASDI program cost as a percentage of GDP. If only a baby boom hump were involved, costs should (approximately) start increasing in 2011 and then revert to the 2010 level sometime in the 2050 to 2060 range, as the last boomers die. Yet the costs climb steadily until 2035, about the middle of an 85 year life span for the boomers, and are then stable out to the horizon, long after they are all dead. There is no pig in the python.

Note that the TF might be said to prefund benefits, to prevent the transfer of part the burden of funding benefits to other generations, but this is not the case. Conceptually, future retirees prefunded some of their retirement by over-paying in payroll tax yesterday. In reality, all future benefits are paid for directly and immediately by workers and taxpayers of that time only. There is no direct or fiscal prefunding, only a possible moral prefunding. It is true that past workers still contributed to society by paying more in payroll tax than was required for then-current benefits, but they were simply paying taxes that needed to be paid anyway, one way or another. They could have just as well paid more in income or other taxes. In any case, all the money was spent on the spot. The TF only enters into this as an accounting mechanism to tell how much future taxpayers should pay in recognition of past payments by workers of regressive payroll taxes. Effectively, a component of past tax paying is being marked as "additional suffering" that warrants payback in the form of "additional suffering" by future generations, where "suffering" refers to use of the regressive payroll tax instead of the progressive income tax. But functionally it is all merely current-period taxes.

There has also been an argument that these "additional" taxes constituted a store of value by leading to an ultimately stronger economy [Smetters 2004]. The claimed mechanism is that they increased national saving because legislators treated "excess" payroll taxes differently from additional income taxes. Regardless of the merit of this argument, it should be clear that the TF played no essential role here: any action that increased national saving would have had the same effect. But, excess payroll taxes are (with current law) gone forever, so right or wrong, this argument is moot.

\section{Public Misunderstanding}

A basic argument of this paper is that the general public does not understand the function of the OASDI TF. Direct evidence of this is lacking, as surveys are not quizzing people on the details of TF function, but rather on their overall view of the OASDI program. However, there is significant indirect evidence of this misunderstanding. This is a problem to the extent that people believe the $\mathrm{TF}$ is more important than it is, even if it need not be any more than it actually is in order to cause payment of benefits. The primary concern is that proper debate cannot be held unless the debaters understand what they are dealing with. The following presents evidence to support the idea of general public misunderstanding, using various arguments.

\subsection{Surveys}

According to a Kaiser Family Foundation survey, $70 \%$ of respondents believe that Social Security will go "bankrupt" if nothing is done [KFF 2005]. This shows a clear misunderstanding of the program, as a pay-as-you-go tax-funded government benefit program cannot go bankrupt, it can only be modified or shut down. This is a political question, not a fiscal one. According to a Washington Post/ABC News poll [WP 2011], $81 \%$ of respondents believe that if changes are not made, the Social Security system is heading for a crisis. $66 \%$ of these believe that major, as opposed to minor, changes are required. Most Americans clearly believe that the Social Security system is in trouble and needs to be "fixed." This would not be the case if it were merely a question of "shall we pay 
the scheduled benefits we have promised?" The mere fact that all survey questions refer to the state of a system indicates that the idea that the entire problem is a moral one is not even registering. People apparently believe that their benefit stream depends on the TF in a fiscal manner, and they are mistaken.

\subsection{SSA FAQ}

The SSA website has a history FAQ, where question 23 is "Has Social Security ever been financed by general tax revenues?," and the brief answer is "Not to any significant extent." There is a more detailed explanation in [SSA 2012a]. This describes three instances of the use of general revenues for SSA funding: credit bonuses for military personnel; special benefits for those who were age 72 before 1971 (presumably deceased by now); and starting with the 1983 amendments, partial income taxes on Social Security benefits. The last item is called "the third and last source of general revenue financing of Social Security."

Clearly missing is the fact that current TF bond redemptions are funded by general revenue. (The web page may or may not be up to date, but this is not relevant, as this is the information available to the public.) So while the "no significant" use of general revenues may be correct from an accounting standpoint by SSA methods, this is clearly not correct on a cash flow basis. Since it is cash flow that determines the affordability of benefits, information such as this is misleading.

There is a similar issue with the "Young Person's Guide" put out by the National Academy for Social Insurance [Edwards 2012]. In the description of program funding, they state: "Social Security is the only major program in the federal budget that is funded entirely by dedicated revenue sources." Again, this conflates moral accounting with fiscal cash flow, contributing to a misleading picture on affordability.

\subsection{The Dedicated Tax}

The payroll tax is described as a "dedicated tax," legally only to be used for Social Security benefits. This widespread description may also be adding to an attitude environment that makes it difficult to understand that higher benefits are affordable. To quote Krugman [Krugman 2005]:

If Ronald Reagan had said, back in the 1980s, "Let's increase a regressive tax that falls mainly on the working class, while cutting taxes that fall mainly on much richer people," he would have faced a political firestorm. But because the increase in the regressive payroll tax was recommended by the Greenspan Commission to support Social Security, it was politically in a different box - you might even call it a lockbox — from Reagan's tax cuts.

What we are doing right now, by redeeming TF bonds through the income tax, is to increase the income tax burden so as not to increase the regressive payroll tax. Permitting the TF to "run out" and not continue to replace the funding through the income tax will effectively be to do as Reagan did, except that instead of raising the regressive payroll tax to finance the income tax cut, we will be cutting Social Security benefits instead. Krugman's two points are still valid: that the action would be unacceptable if understood in this way, and hence that the understanding matters a great deal.

However, surveys show that people are worrying about "bankruptcy" and "fixing" the system, not raising a political firestorm over proposed future cuts. Clearly they do not understand the TF "running out" as a benefit cut paying for a tax cut, although that is the proper fiscal interpretation. One can conclude a lack of public understanding of the TF. 


\subsection{Collective Bargaining Pension System}

Consider a collective bargaining process whereby a pension system is being established. By definition a pension represents deferred compensation, especially if money is being set aside in the present but could instead be paid now. In this case the union has to weigh the value of the future compensation against the risk that it will never be paid. Consider what the union prefers as a means of ensuring that the payments will be made 20 or 30 years in the future. Certainly not a pay-as-you-go system. They would want a trust fund, but funded by what? Formal IOUs? Company stock? Stock for an industry index? A diversified portfolio of stock and bond total index funds? Clearly the options become more appealing to the union as we work further down the list, mostly described by the single word "correlation." The union wants something as uncorrelated as possible with the future fortunes of the company. It is a reasonable assumption that workers intuitively understand this concept of a trust fund, even if they do not mathematically understand correlation. They want their deferred compensation regardless of what happens to the company, and they believe the trust fund is necessary to protect themselves. The TF is manifestly not necessary for the payment of scheduled OASDI benefits. The correlation coefficient to the cash stream is 1, which is not what most people would expect of a trust fund system.

\subsection{Risk}

It is likely that people feel that the concept of a trust fund implies low(er) risk, as the risk of a pay-as-you-go system not delivering is the very thing they are trying to avoid. When great effort is expended to reassure people that the TF is "there," there is a clear implication that the normal cash flow mechanism is risky in some sense, otherwise there would be no need for the allegedly lower-risk trust fund. But the fiscal risks are the same since the funding mechanisms are the same. The only risk is political, and again, the TF is not properly understood.

\subsection{Popular Descriptions}

Consider this episode of "Room For Debate" from the online version of The New York Times [NYT 2011], concerning the TF: The box referring to the main section has this description: "No deception is involved, but the system uses money from new investors to pay earlier investors. How is it different from a Ponzi scheme?" While the authors clearly dismiss the idea that a Ponzi scheme is involved, the text clearly states that money is being "invested," and raising Ponzi addresses fears that the money is being "stolen." Both imply a store of assets that is not present. A later sentence is: "Social Security will not become a pure pay-as-you-go system until 2036 ...". This also implies that assets are involved and is clearly not true. Hence a main paper of record is lately publishing comments that reinforce the basic TF misunderstanding.

\subsection{What Happens at "Run Out" Time}

Consider figures II.D2 (p. 11) and II.D4 (p. 13) of the 2012 Trustees Report. These show that scheduled benefits as a percentage of taxable payroll and GDP are approximately stable from about 2030 onwards. Since the TF is currently estimated to last until approximately 2033, and since it is merely a conduit for pay-as-you-go Treasury funding, benefits will already be fully and stably funded through a combination of payroll and income taxes for several years before the TF is exhausted. This means that once benefits reach their stable level, full benefits are either impossible at any time (even with the current TF balance), or possible without additional burden out to the horizon, without regard to the TF. (Note that the Trustee's Report states that the problem occurs when the TF runs out, not before that time, so no claim is being made that the payroll/income tax burden of the early 
2030s cannot be met.) Anyone who believes that the TF "running out" means that benefits cannot be afforded, especially those worried about "bankruptcy," clearly does not understand this.

Since benefits will already be paying out using the $75 \% / 25 \%$ payroll/income tax revenue mix, nothing actually runs out, rather, there will be a cut in benefits and hence need for revenue. There is no reason to cut benefits unless some other party is to receive that $25 \%$. Regardless of whether this is direct or indirect (by funding a different program) in the long run this amounts to an income tax cut. So the net effect would be to reduce scheduled benefits for retirees in order to give a tax cut to those who pay income taxes, which are not the lower earners. If people understood that an option so stark was on the table, surveys would be making this explicit. From the published surveys it looks doubtful that this point is understood.

\subsection{Summary}

The sum of these arguments is that if everyone clearly understood how the Social Security program and its TF work, many people might consider that they have been sold a significant misrepresentation of the system. Since the current understanding emphasizes problems with assets, whereas the real issue is strictly a political and moral one of whether to pay scheduled benefits, some people could feel that they are being deliberately mislead in order to gain acceptance of modifications that they would not otherwise agree to. Since the TF has no fiscal function, this is a good reason to discontinue its use in public discourse.

\section{Analogies}

Given that the TF is clearly not fiscally required for the payment of OASDI benefits, but that the public believes it is, a basic issue is what tools can be used to help explain TF operation. This section proposes a number of analogies, which are asserted to be accurate representations of the TF, and may be useful as education tools. In particular, they avoid the direct use of financial language such as bonds, IOUs, etc., which clearly have not done the job of enhancing public understanding.

\subsection{TF Bonds as Chits}

A recurring issue is the value of the TF bonds, as described in the introduction. The Trust Fund Paradox is undoubtably confusing to people, as the language used clearly implies that a traditional trust fund is in use. But the bonds are clearly not normal ones, as they cannot be sold, so calling them bonds can be misleading. They are more accurately described as "chits."

To better define a chit, consider a chit system used for a toolroom in a machine shop. A machinist can get use of any tool required, but is not permitted to keep them. Rather, a tool is drawn from the toolroom when needed and returned when the work is done. To ensure return, a chit is required, and each worker has some number of chits, but does not need to pay for them. (This example assumes that no crimes are being attempted, the chits guard only against carelessness and hoarding.) The chit clearly has great value to the worker: no chits, no tools, no work, no job. But the chit has no other value to the worker. It cannot be traded for lunch, used to pay rent, etc. It has no value to the toolroom either: it cannot be used to buy the tool from the supplier, that must have already happened, using real money. A chit for food from the company cafeteria is similar, but it has even less than no value to the cafeteria: they must serve food of value but for no money from the worker, eating the cost from some budget.

This exactly describes the special bonds in the TF. They represent a call on the income tax via Treasury, and hence are clearly of value to the OASDI program. But they cannot be sold on the market, by either the SSA or Treasury, so they have no intrinsic value. The only way for SSA to get money is to turn in the bond and for Treasury to pay from the income tax. The bond is of no help 
to Treasury to get this money. (Even if Treasury could sell them to the public, they are Treasury Bonds and Treasury would still have to pay when they mature.)

So the TF bonds should really be spoken of as chits, which could be issued freely as long as there is a willingness to collect the income tax (in the future) that they represent.

\subsection{The Two Garden Hoses}

Consider attempting to water a front lawn, which requires a certain water flow. Further, the flow required increases in early summer, as it gets hotter, and levels off for the bulk of the summer. The house has a huge service size and can supply water at a far higher rate than required for the lawn. However, the front faucet pipe is small, and can only supply enough flow for spring, and about $75 \%$ of that required for summer. So a hose is run to the back faucet and both are connected to the sprinkler. The front is turned on full and the back is turned on more and more as required, but is never anywhere near full open.

There is a catch. The backyard goblin believes he owns water coming from the back faucet, and is not willing to part with an arbitrary amount. So he puts a meter in the hose line, and after a while, shuts off the valve for good, even though there is plenty of capacity serving the entire house.

The house water service is the US economy, the front faucet is the payroll tax, the back faucet is the income tax, and the meter represents the TF balance. The goblin represents a decision to refuse to permit the income tax to pay $25 \%$ of OASDI scheduled benefits past a certain point. The apparent arbitrariness of the goblin represents the current use of the TF balance as a cutoff point. The question for the lawn is where to send the back faucet water, not whether it is available, and the same holds for scheduled OASDI benefits: they are affordable, the only question is whether to pay them.

\subsection{The Water Treatment Plant and the Water Tank}

This analogy gets more directly to the function of the TF itself, and probably closely matches people's notion of what a trust fund is like. The heart of the matter is that people probably perceive a trust fund to be something that can supply cash flow in spite of the loss of the original source of revenue. Here a water tank is used as an analogy for a trust fund, to supply a constant flow even if original production ceases. Water plant analogies are used to compare a generic deferred compensation scheme to a private pension plan and the OASDI program. In Figures 1 to 3 a water treatment plant produces drinking water instead of cash flow. It has provision for selling water for current consumption, or selling it now but for later delivery, or deferred consumption.

Figure 1 shows a basic system. Two pipes leave the plant, one going to "current consumption" and one to "deferred consumption." The valve marked "management" represents the ability to curtail the latter. As long as the plant has sufficient capacity, and management is not greedy, the deferred water is supplied. If the plant ceases to function, the promised deferred water is not delivered, even though it has been paid for. This is a significant concern for anyone considering paying now for deferred consumption.

Figure 2 is the analogy for a traditional private pension plan, where the water tank is the solution to a lack of confidence in future delivery. Here a branch line from "current consumption," still with a valve to represent choice in funding, adds water to the tank. The line to "deferred consumption" can be supplied indirectly from the plant (through the tank) or from the tank alone. Part of current output is stored, so, given sufficient tank holdings, the promised deferred water can be delivered even if the plant were to disappear. The Pension Benefit Guaranty Corporation (PBGC) "plant" can also deliver water to the deferred customers, with the valve representing possible limits on covered 
benefits. To the extent that we believe that PBGC obligations will ultimately be backed by the Federal government, this PBGC "plant" is the entire US economy.

Figure 3 is the analogy for the OASDI program. The "plant" is the entire US economy. There are two pipes leading to the "Y" that supplies the "benefits" group. The first is current cash flow, as in a traditional pay-as-you-go system. It has a valve on it, representing the limits of current-period payroll tax revenue. The other pipe comes from Treasury (income tax) and is the "trust fund," but there is no tank, it leads back to the same plant. This is because Treasury cannot redeem TF bonds without resort to the income tax, as discussed before. The meter and valve on this pipe represent the notional balance in the TF; when the meter hits zero, the valve is closed, but the capacity of the plant (economy) is not affected and could continue producing at its previous rate without regard to the meter. There is a valve on the final output pipe, representing the fact that benefits can be changed in any way at any time. OASDI payments can be made only from revenue taxed from the economy, regardless of whether this comes from the payroll or income tax.

There is manifestly no tank in the OASDI system, so the OASDI program is accurately represented by Figure 3, not Figure 2. The TF misunderstanding is that the public perception is the opposite, that the TF is analogous to Figure 2 rather than Figure 3. When the public is concerned about "bankruptcy," it believes there is a "tank," that it will run dry, and that there is no way to refill it. The counter-argument is that what is perceived as the tank and the "fill faucet" are really the income tax, that the "faucet" is already cracked, and can be easily turned on much harder.

\subsection{Hot Water Heaters}

A simplified alternative to the water supply analogy is a tank vs. tankless hot water heater, where the "product" is hot water. In a tank hot water heater, water can be continuously heated as it flows through the tank, but only at a limited rate. If the entire tank has been preheated, hot water can be withdrawn at a much higher rate, but only up to a limited quantity. Then the tank "runs out" and the rate is again restricted. A tankless heater has a maximum rate with no ability to exceed, but generally a higher rate than a tank heater once the tank has been emptied of its preheated water.

A tank hot water heater is the proper analogy for a trust fund benefit system. Pre-funding of the trust fund represents water preheated in the tank. The continuous heating rate represents the future pay-as-you-go capability, while exceeding that rate represents the temporary ability of the tank to supply flow beyond that continuous rate. If the burner fails, analogous to failure of the company funding the benefits, the tank can supply a limited quantity thereafter. This is likely to be the analogy understood by people thinking of a trust fund.

A tankless heater is analogous to a pay-as-you-go benefit system. It must be capable of supplying the maximum required flow, but supplies nothing if it fails. The proper analogy for the OASDI system is a pair of parallel tankless heaters. The larger heater represents the payroll tax, and has a maximum capacity of $75 \%$ of the maximum load. The smaller heater represents the income tax, and can carry the rest of the load. Importantly, the fuel supply (analogous to the economy) is adequate for both heaters at full load.

The basic misunderstanding of the TF is that it is being described, and understood, as a tank heater, when there is actually no tank. This can explain why the public will accept the claim that the TF "run out" must reduce benefits. The previous payment of excess payroll taxes is understood as filling the tank with preheated water, which is now being drained. People understand that once the tank runs out of hot water, it can never be re-heated if the shower cannot be turned off. Hence, the claim of a necessity of benefit cuts makes sense. The reality of the parallel tankless heaters supplies the counter-argument, by showing that the "run out" claim is equivalent to deciding that the smaller heater shall be turned off merely to reduce the fuel bill. 


\section{Affordability Arguments and Data}

The main premise of this paper, that the public misunderstands the TF and hence is debating the wrong aspects of the program, implicitly rests on the assumption that the program is affordable. "Affordable" means that we can choose to have it if we want. This would not the case if a reasonable projection of the cost is, say, $100 \%$ of GDP. Affordability of scheduled benefits is obvious in that the program cost is currently $5 \%$ of GDP, and is predicted to rise to a peak of around $6.4 \%$, then settle to around $6 \%$ to the horizon. Since the US is currently one of the most lightly taxed countries in the OECD, an increase in transfer payments by $1 \%$ of GDP is clearly manageable. (This is not a claim that the decision to do this is obvious, only that it is obviously affordable, so that we can freely choose to pay, or not.)

However, given the large part of the population that believes that the program is in trouble and needs a major fix, it is not clear that this affordability is obvious to them. Since a likely public understanding of the TF is that there is a tank, the belief that the system is in trouble implies a belief that refilling the tank is not affordable. Since there is no tank, this is the same as a belief in general unaffordability. Hence, this section presents a number of arguments that are proposed as being useful for public education on this component.

In the following, unless otherwise specified, data comes from the 2012 Trustees Report (hereafter, the "TR"), prepared based on 2011, using the intermediate assumptions [SSA 2012b]. This is consistent with general practice, as the TR lays out the generally accepted parameters for evaluating the overall program. (While the disability insurance portion is not a subject of this paper, it is frequently lumped with OAS in reports, so this is done here. On a cost basis, DI was about $18 \%$ of the OASDI cost in 2011.)

\subsection{General Data}

Table 1 column 4 gives the projected total OASDI cost as a percentage of GDP, from TR Table VI.F4 (TR p. 197).

This is projected to rise from the current level of $5.0 \%$ to about $6.4 \%$ in 2035 , decline to $6.1 \%$ by 2050 , and to remain between $6.0 \%$ and $6.1 \%$ through 2090. This is a maximum increase of about 1.4 percentage points of GDP, about a quarter increase in the OASDI share of GDP. For the steady state level, this is a 1 percentage point increase, a fifth of the OASDI share. For reference, the projected GDP and costs are given in billions of 2011 dollars in columns 2 and 3. The nominal GDP is from TR Table VI.F4 and this is adjusted to 2012 by using the "Adjusted CPI" column from TR Table VI.F6 (TR p. 202). From Table 2, total federal spending in 2011 was around $24 \%$ of GDP, so an additional 1-1.4 percentage points would be manageable.

\subsection{Continuity}

This argument is one of continuity across the boundary of the TF running out. Before access to Treasury funding is cut off, the OASDI program will already be at approximately peak cost as a percentage of payroll and GDP, using approximately a $75 \% / 25 \%$ payroll to Treasury funding mix, the same mix that will prevail out to the horizon. Since there is no fiscal change across this boundary, either the benefits can or cannot be paid, identically before and after. The warnings about the TF balance are what happens when it "runs out." The TR does not have any warnings about not being able to redeem TF bonds, and supporters appear to exclusively state that the bonds are "good." It is clearly held that the program will pay scheduled benefits with the $75 / 25$ mix into the 2030 's, so the logical conclusion is that they can be continued out to the horizon. 
OASDI Program Costs

\begin{tabular}{rrrrrrr}
\cline { 3 - 6 } & & & & \multicolumn{2}{c}{ \% Taxable Income } \\
\cline { 3 - 6 } Year & GDP $(\mathbf{B} \$)$ & Cost $\mathbf{( B \$ )}$ & \%GDP & Current & $\mathbf{1 . 2 6}$ & $\mathbf{1 . 2 1}$ \\
\hline 2012 & $\$ 15,757$ & $\$ 789$ & $5.01 \%$ & $13.83 \%$ & $10.98 \%$ & $11.43 \%$ \\
2013 & $\$ 16,130$ & $\$ 816$ & $5.06 \%$ & $13.95 \%$ & $11.07 \%$ & $11.53 \%$ \\
2014 & $\$ 16,635$ & $\$ 847$ & $5.09 \%$ & $13.98 \%$ & $11.10 \%$ & $11.55 \%$ \\
2015 & $\$ 17,233$ & $\$ 879$ & $5.10 \%$ & $13.97 \%$ & $11.09 \%$ & $11.55 \%$ \\
2016 & $\$ 17,812$ & $\$ 910$ & $5.11 \%$ & $13.94 \%$ & $11.06 \%$ & $11.52 \%$ \\
2017 & $\$ 18,332$ & $\$ 942$ & $5.14 \%$ & $13.91 \%$ & $11.04 \%$ & $11.50 \%$ \\
2018 & $\$ 18,808$ & $\$ 976$ & $5.19 \%$ & $13.96 \%$ & $11.08 \%$ & $11.54 \%$ \\
2019 & $\$ 19,178$ & $\$ 1,013$ & $5.28 \%$ & $14.13 \%$ & $11.21 \%$ & $11.68 \%$ \\
2020 & $\$ 19,513$ & $\$ 1,050$ & $5.38 \%$ & $14.37 \%$ & $11.40 \%$ & $11.88 \%$ \\
2021 & $\$ 19,847$ & $\$ 1,090$ & $5.49 \%$ & $14.65 \%$ & $11.63 \%$ & $12.11 \%$ \\
2025 & $\$ 21,235$ & $\$ 1,251$ & $5.89 \%$ & $15.88 \%$ & $12.60 \%$ & $13.12 \%$ \\
2030 & $\$ 23,083$ & $\$ 1,443$ & $6.25 \%$ & $17.01 \%$ & $13.50 \%$ & $14.06 \%$ \\
2035 & $\$ 25,182$ & $\$ 1,602$ & $6.36 \%$ & $17.41 \%$ & $13.82 \%$ & $14.39 \%$ \\
2040 & $\$ 27,527$ & $\$ 1,737$ & $6.31 \%$ & $17.36 \%$ & $13.78 \%$ & $14.35 \%$ \\
2045 & $\$ 30,069$ & $\$ 1,867$ & $6.21 \%$ & $17.19 \%$ & $13.64 \%$ & $14.21 \%$ \\
2050 & $\$ 32,746$ & $\$ 2,004$ & $6.12 \%$ & $17.08 \%$ & $13.56 \%$ & $14.12 \%$ \\
2055 & $\$ 35,595$ & $\$ 2,164$ & $6.08 \%$ & $17.09 \%$ & $13.56 \%$ & $14.12 \%$ \\
2060 & $\$ 38,681$ & $\$ 2,344$ & $6.06 \%$ & $17.16 \%$ & $13.62 \%$ & $14.18 \%$ \\
2065 & $\$ 42,063$ & $\$ 2,541$ & $6.04 \%$ & $17.20 \%$ & $13.65 \%$ & $14.21 \%$ \\
2070 & $\$ 45,724$ & $\$ 2,762$ & $6.04 \%$ & $17.33 \%$ & $13.75 \%$ & $14.32 \%$ \\
2075 & $\$ 49,676$ & $\$ 3,000$ & $6.04 \%$ & $17.46 \%$ & $13.86 \%$ & $14.43 \%$ \\
2080 & $\$ 53,926$ & $\$ 3,268$ & $6.06 \%$ & $17.60 \%$ & $13.97 \%$ & $14.55 \%$ \\
2085 & $\$ 58,472$ & $\$ 3,561$ & $6.09 \%$ & $17.79 \%$ & $14.12 \%$ & $14.70 \%$ \\
2090 & $\$ 63,374$ & $\$ 3,885$ & $6.13 \%$ & $17.98 \%$ & $14.27 \%$ & $14.86 \%$ \\
& & & & & &
\end{tabular}

Table 1. OASDI program costs. Dollar amounts in 2012 dollars.

\subsection{General Program Costs}

For a comparison of the major Federal program costs, see Table 2. The data comes from pp. 13-14 of [US Treasury 2011] and shows the cost of general federal functions as dollars and a percentage of GDP. Social Security is $20 \%$ of 2011 federal spending, less than that spent on health programs, similar to that for defense, and $22 \%$ more than spent on income security. Using the TR percentage increase in GDP share of $5.0 \%$ to $6.1 \%$ out to the horizon, this would represent a spending increase to $\$ 929 \mathrm{~B}$ by Treasury's accounting. This would make OASDI $24 \%$ of the increased total outlay, all else the same. So it would take about the same percentage of the budget as health does now. 


\begin{tabular}{lrrr}
\multicolumn{1}{c}{ Category } & Cost (B\$) & \%GDP & \%Spending \\
\hline Health \& Medicare & $\$ 858$ & $5.64 \%$ & $24 \%$ \\
Social Security & $\$ 731$ & $4.80 \%$ & $20 \%$ \\
National Defense & $\$ 708$ & $4.65 \%$ & $20 \%$ \\
Income Security & $\$ 599$ & $3.93 \%$ & $17 \%$ \\
All Other & $\$ 702$ & $4.61 \%$ & $19 \%$ \\
& & & \\
Total & $\$ 3,598$ & & \\
GDP & $\$ 15,231$ & &
\end{tabular}

Table 2. Federal spending on programs in 2011.

The projected increase in OASDI cost can also be compared to past increases in national defense costs. The Census Bureau has a table of defense outlays as a percentage of GDP for various years from 1960 to 2010 [Census Bureau 2012]. As recently as the 2002-2009 interval, defense outlays increased by $1.4 \%$ of GDP. This is the same maximal OASDI increase, but took place over only 7 years, while the OASDI program will take 23 years. Hence not only is the OASDI program level commensurate with that of other programs, but its rate of increase is lower. A similar point is made by the increase in public spending for education, which grew 2.9 percentage points of GDP from 1950 to 1975, twice the projected increase in OASDI costs over approximately the same period [NASI 2012].

\subsection{OECD Comparison}

For a different comparison, consider the level of public pension expenditure as a percent of GDP for various OECD countries. In [Baily 2009] on p. 9, data shows that US public pension expenditure was around $4.5 \%$ in 2005 and projected to rise to around $6.5 \%$ in 2050. By the same measurement, the OECD average was around $8.5 \%$ in 2005 and projected to rise to around $13 \%$ in 2050 . In [OECD 2011a] on p. 159, US expenditure was at $4.6 \%$ in 2010 and projected to rise to $4.8 \%$ in 2050, while the comparable figures for the OECD28 were $8.4 \%$ and $11.4 \%$. By both measures, the projected level of US public pension expenditure in 2050, past and lower than its predicted peak, is less than the current OECD average. Since the OECD countries have been able to manage their pensions to date, our burden is clearly manageable.

Consider the total tax revenue as a percentage of GDP for the OECD for 2009 [OECD 2011b]. This ranges from Mexico at $17.4 \%$ to Denmark at $48.1 \%$, with an unweighted average of $33.8 \%$. The US burden is $24.1 \%$, higher than that of only Mexico and Chile, out of 34 countries. If revenue was increased by $1 \%$ of GDP, to cover the cost of scheduled benefits out to the horizon, the US would pass only one more country, Turkey. Even with raising taxes to cover scheduled benefits, the US would remain one of the most lightly taxed countries in the OECD.

\subsection{Cash Flow Affordability}

The most obvious question for future employees and taxpayers will be the cash flow consequences of future scheduled benefits, i.e., how much will taxes go up?

Table 1 column 5 gives the projected benefits based on current law, as a percentage of projected taxable income, from TR table VI.F2 (TR p. 192). The percentage of taxable income represents the combined employer and employee rate necessary to fund the entire cost for that year. Taxable income was the first $\$ 106,800$ for each employee in 2011 , at a rate of $12.4 \%$ (TR p. 6-7). Note that the temporary employee payroll tax reduction does not affect SSA revenue, as the uncollected tax is made up by Treasury (TR p. 6). This peaks at $17.98 \%$ in 2090, meaning the employee share would 
be $8.99 \%$ instead of the current $6.2 \%$, an increase of 2.79 percentage points. If the Medicare rate were to remain the same as now, the employee would be paying $10.44 \%$ instead of the current $7.65 \%$ (absent the temporary reduction). So if the payroll tax rate is adjusted to meet costs, the additional payroll tax in 2012 dollars, for a worker making $\$ 50,000$ per year, would be about $\$ 560$ in 2021 , $\$ 1,150$ in 2030 and $\$ 1,395$ in 2090. This would be an average increase of around $\$ 60 /$ year through 2030 , and around $\$ 4 /$ year thereafter. Even this simple approach, maintaining the regressive payroll in its current form, would seem to be manageable.

Now consider using the income tax to make up the payroll tax shortfall, exactly what is being done now and will be done until the TF runs out. Consider the 2010 data, from [SSA 2011], as this corresponds to IRS income tax data availability [Dungan 2012]. The total OASDI program cost for 2010 was $\$ 713 \mathrm{~B}$ with non-interest income of $\$ 664 \mathrm{~B}$. The payroll tax income is at a rate of $12.4 \%$, so the approximate taxable payroll is $\$ 5,355 \mathrm{~B}$. The shortfall for 2010 was $\$ 49 \mathrm{~B}$. Using the maximum OASDI cost as a percentage of taxable payroll, in 2090 , of $17.98 \%$, this would imply a maximum shortfall of $\$ 299 \mathrm{~B}$, in 2010 dollars. In 2010 the federal income tax liability was $\$ 987 \mathrm{~B}$. Hence in 2010, $4.96 \%$ of the federal income tax liability went to fund OASDI payments, and in 2090 the liability would need to be about $25 \%$ higher than the 2010 level to fund the complete shortfall. However, this figure does not fairly represent the burden. The total Adjusted Gross Income for 2010 was $\$ 8,045 \mathrm{~B}$ while the taxable income was $\$ 5,459 \mathrm{~B}$. So the additional shortfall for the 2090 rate $(\$ 250 \mathrm{~B})$ would amount to $3.11 \%$ of AGI and $4.58 \%$ of taxable income.

More generally, current taxable income is about the same as current taxable payroll, and together these two taxes make up most of federal revenues ( $82.4 \%$ in 2011, [JCT 2011]). So the additional revenue needed (above the current shortfall) for the peak cost is around two and a quarter percent of the combined income and payroll tax base.

Note also that the income tax figures are for a period of recession. In 2010 the income tax liability increased $8.4 \%$ from 2009 . The liability represented $18 \%$ of taxable income, so in one year alone the income tax take increased by $1.5 \%$ of taxable income. So the increase in income tax would appear manageable.

\subsection{Affordability Using an Alternate Payroll Tax Base}

One of the arguments against allowing the income tax to be used (at least visibly) to fund OASDI benefits is that this weakens the link between taxes and benefits. This has been aimed against the temporary payroll tax reduction. The question is whether future scheduled benefits can be made more affordable while using only payroll taxes. An obvious option is to remove the contribution cap, but not change the benefit schedule. This would have the beneficial side effect of making the payroll tax less regressive. (It would be flat on covered income only; since higher earners have more non-covered income, the payroll tax would still be regressive across all income.)

There are three sources of information on the effects of removal of the contribution cap. The first would be to assume that the OASDI contribution base becomes the same as the HI base. On p. 189 of the TR, the differences between the OSADI and HI wage bases are briefly described, and involve a larger pool of workers under HI, so the difference is not solely the lack of an HI cap. So even with keeping the benefit cap, system costs may expand if the pool were increased. But as a crude comparison, the report states that "the HI taxable payroll is about 26 percent larger than the OASDI taxable payroll throughout the long-range period." So column 6 of Table 1 simply divides column 5 by 1.26 , giving the combined employer/employee contribution rate required to cover costs assuming the same base as the HI program.

For the second source, consider the coverage rate as described on pp. 134-137 of the TR. This is the percentage of all covered wages that is at or below the cap. This was $88.1 \%$ in $1984,82.5 \%$ in 2000 , and $83.9 \%$ in 2010 . The 2012 TR estimates a rate of $82.5 \%$ for 2021 , and states that this is the same as estimated in the 2011 TR ([SSA 2011], pp. 114-155). However, the published figure was 
$82.9 \%$ for 2020, and then was predicted to remain steady out to the horizon. If we assume that the 2012 TR rate of $82.5 \%$ holds steady, removal of the contribution cap with no other changes would lead to payroll tax income about $21 \%$ higher over the long term. (This is unchanged if the $2011 \mathrm{TR}$ steady-state figure of $82.9 \%$ is used.) Column 7 of Table 1 shows the resulting contribution rates. The OASDI rate would drop 0.97 percentage points immediately, would return to current levels sometime before 2025 , and would climb to 2.46 percentage points over the current in 2090 . Hence in 2090 the employee would be paying $1.23 \%$ of wages in payroll tax over the current level. At $\$ 50,000$ annual salary, this would be $\$ 615$ /year (2012 dollars).

Finally, the Congressional Research Service (CRS) examined this issue, described in [Mulvey 2010]. The conclusion in the summary (p. 2) is that "If all earnings were subject to the payroll tax, but the base was retained for benefit calculations, the Social Security Trust Funds would remain solvent for the next 75 years."

Clearly, the payroll tax alone can be made to cover the entire cost with modest tax increases to all but the highest earners, and with a tax reduction on earners under the cap for the next 20 years. Further, eliminating the cap would make the payroll tax less regressive. The CRS report adds the caveat "However, having different bases for contributions and benefits would weaken the traditional link between the taxes workers pay into the system and the benefits they receive." How much this would weaken the link is debatable, as the link has never been linear ([Altman 2005], p. 82). There are currently two bend points (see TR p. 111), and earnings over about $\$ 55,000 /$ year have only a $15 \%$ replacement rate. Leaving the cap for benefits would simply add a third bend point, with a $0 \%$ replacement rate above the cap, resulting in a replacement rate progression of $90,32,15$ and $0 \%$. An alternative would be to add a fourth bend point for $0 \%$, out at a level where there is no sympathy $(\$ 250,000 ?)$, and have a very low replacement rate between that and the current cap.

Further evidence against the strength of this link in the public view is provided by a National Academy of Social Insurance survey from 2009 [Reno 2009]. When asked about willingness to pay (Table 7), $87 \%$ were willing "because it provides security and stability to millions of retired Americans, the disabled, and the children and widowed spouses of deceased workers," while only $72 \%$ were willing because "I know that I will be receiving the benefits when I retire." There is clearly an attitude of contributing to others instead of just ones self, which can be done in any tax form. When asked which of various options they supported for raising revenue (Table 8), removing the tax cap got the largest agreement, $83 \%$ and the smallest do not know, $1 \%$. This would indicate people favor extending the tax to the more wealthy over maintaining the current level of linkage, although the report did not make clear how well the respondents understood the caps.

\subsection{Stimulus}

A final argument for affordability is to consider whether it is affordable (to the economy) to not continue paying scheduled benefits after the TF run-out date. With OASDI benefits to be at around $6 \%$ of GDP and the payroll tax shortfall to be around $25 \%$, cutting benefits would be a transfer of $1.5 \%$ of GDP from retirees to those paying the income tax. This could be significant depending on the relative propensity to spend of the two groups. This will not be analyzed in detail here, but a rough case can be made by considering that the income tax will go primarily to higher earners who save more, while most older people spend most of their income. This means that maintaining the status quo would constitute some level of stimulus compared to cutting benefits. The spending of old-age benefits can be considered from two viewpoints.

First, a significant number of people find their Social Security benefits to be essential, many more than thought so prior to retirement. In EBRI's 2011 Retirement Confidence Survey ([Helman 2011], p. 33), $33 \%$ of workers expect Social Security to be major source of income, and an additional $45 \%$ expect it to be a minor source. However, among retirees $68 \%$ state that it is a major source, and $23 \%$ a minor one. The Kaiser Family Foundation 2005 Social Security Knowledge Poll ([KFF 2005]) 
found that $51 \%$ of retirees said that Social Security was their largest source of income. An analysis of the 2010 Current Population Survey by the Institute for Women's Policy Research [Hartmann 2011] shows that for men and women 65 and over, $56 \%$ and $67 \%$ of their income on average, respectively, comes from Social Security. Since the OASDI program was intended to cover only a portion of retirement income requirements, and since many people are surprised by how little else they have, the fact that it is a major or largest source for most people would imply that it is mostly being spent on essential goods and services rather than being saved.

The other viewpoint is to consider expenditures by households aged 65 and over. In [BLS 2011] the Consumer Expenditure Survey data for 2010 shows that that for this age group, $78 \%$ of expenditures went to food, housing, transportation, healthcare, and apparel and services. In [Lafrance 2011], using Canadian cohorts entering their late sixties and early seventies, the consumption to income ratio is between 0.96 and 0.98 , so almost all their income is being spent. $85 \%$ to $88 \%$ of this consumption was for essential categories similar to those used in the BLS data. In [Butrica 2005] data from the Health and Retirement Study is used. For ages 65-74, the expenditure to after-tax income ratio is 0.81 , and for 75 and over the ratio is 0.91 . For ages 65 and over, essential categories are $76 \%$ of expenditures. This percentage is in the 70's for all income quintiles. So it is clear that people in the retirement age range are spending most of their income, and of that, most is being spent on essential goods and services.

\section{Conclusion}

The OASDI Trust Fund is a misrepresentation of its own concept. It is not a trust fund in the traditional sense as it does not perform the essential function of maintaining a payment stream in the event of collapse of the original source of the funds. It contains no assets that can independently produce income; the special bonds in the TF should be considered budget authority or chits instead. The ultimate source of OASDI payments is the US economy, tapped through a combination of the payroll and income taxes. The TF serves only to alter the distribution between the two and limit access to the latter. If the economy cannot provide sufficient funds to make scheduled payments in the future, the payments will not be made, with or without the TF.

Public discourse indicates that people do not understand this. Reassurance that the TF is sound is a claim that it has an independent fiscal significance. Survey questions concerning the state of Social Security rather than the moral issue of whether to fund scheduled benefits indicate the same problem: the universe of discourse is on the soundness of a trust fund that cannot be sound or unsound. The responses to survey questions indicate that people believe the system is unsound, and that they miss the political nature of the payment decision.

By various measures, the increased revenue to fund scheduled benefits out to the horizon is easily manageable. This is the case even if the existing payroll tax structure is kept in place, with the rate adjusted as necessary. This is true on a cash flow basis, which will be the concern of workers. All else the same, in 2090, the peak year within the horizon, a worker would be paying an additional $2.79 \%$ of covered income in order to fully fund benefits as currently scheduled. By keeping everything the same except for the rate, and dropping the contribution cap, the maximum increase would be $1.23 \%$ of wages, in 2090 . This is clearly manageable, although still regressive. If the payroll tax rate were frozen at the current $12.4 \%$ and the contributions cap lifted, the balance at the peak cost could be made up by the federal income tax for an additional $2 \%$ of taxable income, based on 2010 parameters. This would fall mainly on higher earners.

The peak scheduled benefits are similarly manageable from the point of view of overall burden. The peak cost as a percentage of GDP occurs in 2035, at $1.35 \%$ higher than current. This estimated peak percentage is below the current average pension percentage for the OECD. So the peak burden is clearly manageable by comparison. 
The debate over the TF and its solvency therefore misses the point. As a tax-funded pay-as-you-go system, there is no concept of bankruptcy. The "solvency" of the TF as a store of assets is the same as the health of the US economy, since all funds provided by the TF come immediately and directly from the economy. So the only real issue is what to do around 2033 when the TF "runs out," causing the SSA to lose budget authority to tap the income tax for revenue. Under current law, the payroll tax will only be adequate for around $75 \%$ of then scheduled benefits. Raising taxes to cover the full scheduled benefit level is clearly a viable option. Hence, the debate must be over whether to do this, or more generally, what mix of tax increases and benefit cuts should be made to bring the two into balance. This is strictly a moral and political issue, far removed from a discussion of asset solvency.

The current misunderstanding of the TF leaves the possibility that its continued existence may continue to cloud the debate, and be used to justify program changes that would not be acceptable if the program was properly understood. This is an argument for abandoning the TF completely. An easier and probably more palatable option would be to re-institute full recourse to Treasury for any future shortfall, as was the case during the 1940's. This would mean that any time the TF is running low, Treasury would supply funds by any convenient method. In effect nothing would change, as this would mean supplying general revenue (ultimately from the income tax), exactly as is happening right now. The only difference would be that this recourse would be unlimited, whereas now the TF "balance" specifies a limit to total income tax liability. This would mean that OASDI payments would be defined by the benefit schedule rather than the revenue schedule. Then, the Social Security debate would immediately shift to "what part of the scheduled benefits should be paid," and how to adjust the tax structure to meet the need, which is where the debate needs to be. 


\section{References}

AARP. 2010. Social Security 75th Anniversary Survey Report: Public Opinion Trends. (August). Washington, DC: AARP.

Altman, N. J. 2005. The Battle for Social Security: From FDR's Vision to Bush's Gamble. Hoboken, NJ: John Wiley \& Sons. ISBN 978-0-471-77172-2.

Altman, N. J. 2010. "Demystifying Social Security Financing and the General Fund." Poverty and Public Policy, vol. 2, no. 1, pp. 9-16.

Baily, M. N. and J. F. Kirkegaard. 2009. US Pension Reform: Lessons From Other Countries. Washington, DC: Peterson Institute for International Economics. ISBN 978-0-88132-425-9.

Baker, D. and M. Weisbrot. 1999. Social Security: The Phony Crisis. Chicago: The University of Chicago Press. ISBN 0-226-03544-1.

Bartlett, B. 2011. "The Real Social Security and Medicare Problem (and a Doable Fix)." The New York Times (May 17), Online. Available at http://economix.blogs.nytimes.com/2011/ 05/17/the-real-social-security-and-medicare-problemand-a-doable-fix/?hp.

BLS. 2011. Consumer Spending in 2010. Focus on Prices and Spending, Volume 2, Number 12 (December). Washington, DC: Bureau of Labor Statistics.

Butrica, B. A., J. H. Goldwyn and R. W. Johnson. 2005. Understanding Expenditure Patterns in Retirement. Working Paper 2005-03 (January). Chestnut Hill, MA: Center for Retirement Research at Boston College.

Census Bureau. 2012. http://www.census.gov/compendia/statab/2012/tables/12s0503.pdf, accessed August 21.

Diamond, P. A. and P. R. Orszag. 2004. Saving Social Security: A Balanced Approach. Washington, DC: Brookings Institution Press. ISBN 0-8157-1383-1.

Dungan, A. and M. Parisi. 2012. "Individual Income Tax Returns, Preliminary Data, 2010." SOI Bulletin (Winter), pp. 5-18.

Edwards, K. A., A. Turner and A. Hertel-Fernandez. 2012. A Young Person's Guide to Social Security. Washington, DC: National Academy of Social Insurance.

Hartmann, H., J. Hayes and R. Drago. 2011. Social Security: Especially Vital to Women and People of Color, Men Increasingly Reliant. Report D494 (January). Washington, DC: Institute for Women's Policy Research.

Helman, R., C. Copeland and J. VanDerhei. 2011. The 2011 Retirement Confidence Survey. Issue Brief 355 (March). Washington, DC: Employee Benefit Research Institute.

JCT. 2011. Joint Committee on Taxation Testimony. JCX-49-11 (September 22). Washington, DC: Joint Committee on Taxation.

KFF. 2005. Kaiser Family Foundation/Harvard University/Washington Post Poll: Social Security Knowledge Poll. (February 3-6). Menlo Park, CA: Kaiser Family Foundation.

Krugman, P. 2005. "Confusions about Social Security." The Economist's Voice, vol. 2, no. 1, pp. 1-9. 
Lafrance, A. and S. Larochelle-Cote. 2011. Consumption Patterns Among Aging Canadians: A Synthetic Cohort Approach. Economic Analysis Research Paper Series 11F0027M2011067 (March). Ottawa: Statistics Canada.

Mulvey, J. 2010. Social Security: Raising or Eliminating the Taxable Earnings Base. (September 24). Washington, DC: Congressional Research Service.

NASI. 2012. http://www.nasi.org/learn/socialsecurity/economy-share, accessed August 24.

NYT. 2011. "Room For Debate: Ponzi Scheme?" The New York Times (September 8), Online. Available at http://www.nytimes.com/roomfordebate/2011/09/09/is-social-security-a-ponzischeme?hp.

OECD. 2011a. Pensions at a Glance 2011: Retirement Income Systems in OECD and G20 Countries. OECD Publishing. ISBN 978-92-64-09523-6.

OECD. 2011b. Revenue Statistics 1965-2010. OECD Publishing. ISBN 978-92-64-12285-7.

Reno, V. P. and J. Lavery. 2009. Economic Crisis Fuels Support for Social Security: Americans' Views on Social Security. (August). Washington, DC: National Academy of Social Insurance.

Smetters, K. 2004. "Is the Social Security Trust Fund a Store of Value?" The American Economic Review, vol. 94, no. 2, pp. 176-181.

SSA. 2011. The 2011 Annual Report of the Board of Trustees of the Federal Old-Age and Survivors Insurance and Federal Disability Insurance Trust Funds. (May 13). Washington, DC: Social Security Administration.

SSA. 2012a. http://ssa.gov/history/genrev.html, accessed August 23.

SSA. 2012b. The 2012 Annual Report of the Board of Trustees of the Federal Old-Age and Survivors Insurance and Federal Disability Insurance Trust Funds. (April 25). Washington, DC: Social Security Administration.

US Treasury. 2011. Combined Statement of Receipts, Outlays, and Balances of the United States Government. Washington, DC: US Treasury.

WP. 2011. Washington Post-ABC News Poll. (March 10-13). Washington, DC: Washington Post. 


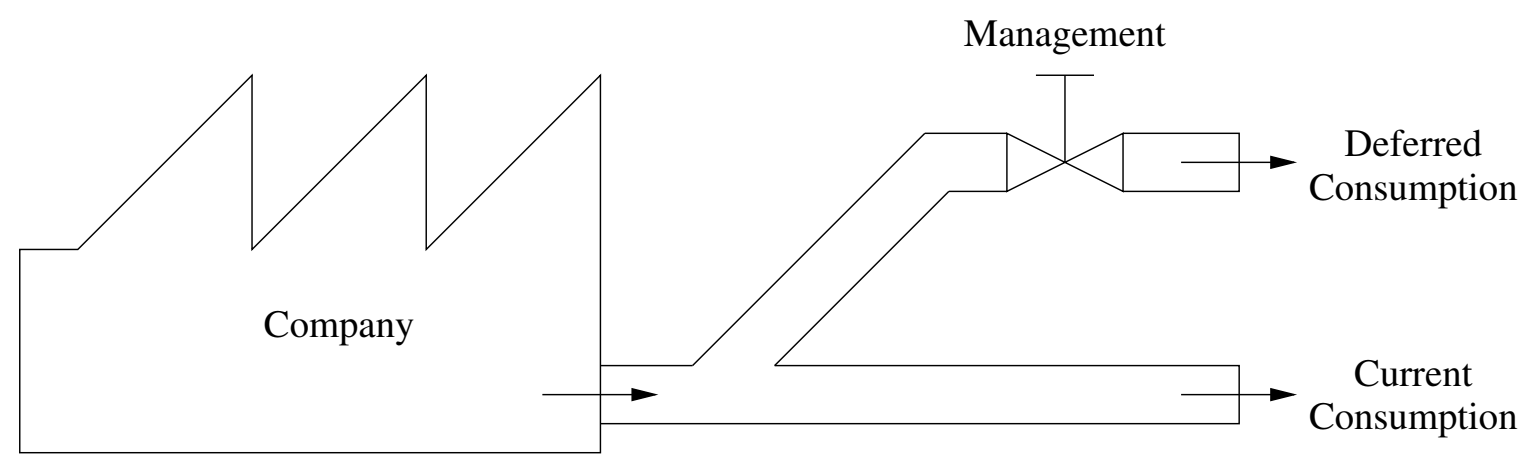

Figure 1. Analogy for a basic deferred compensation system.

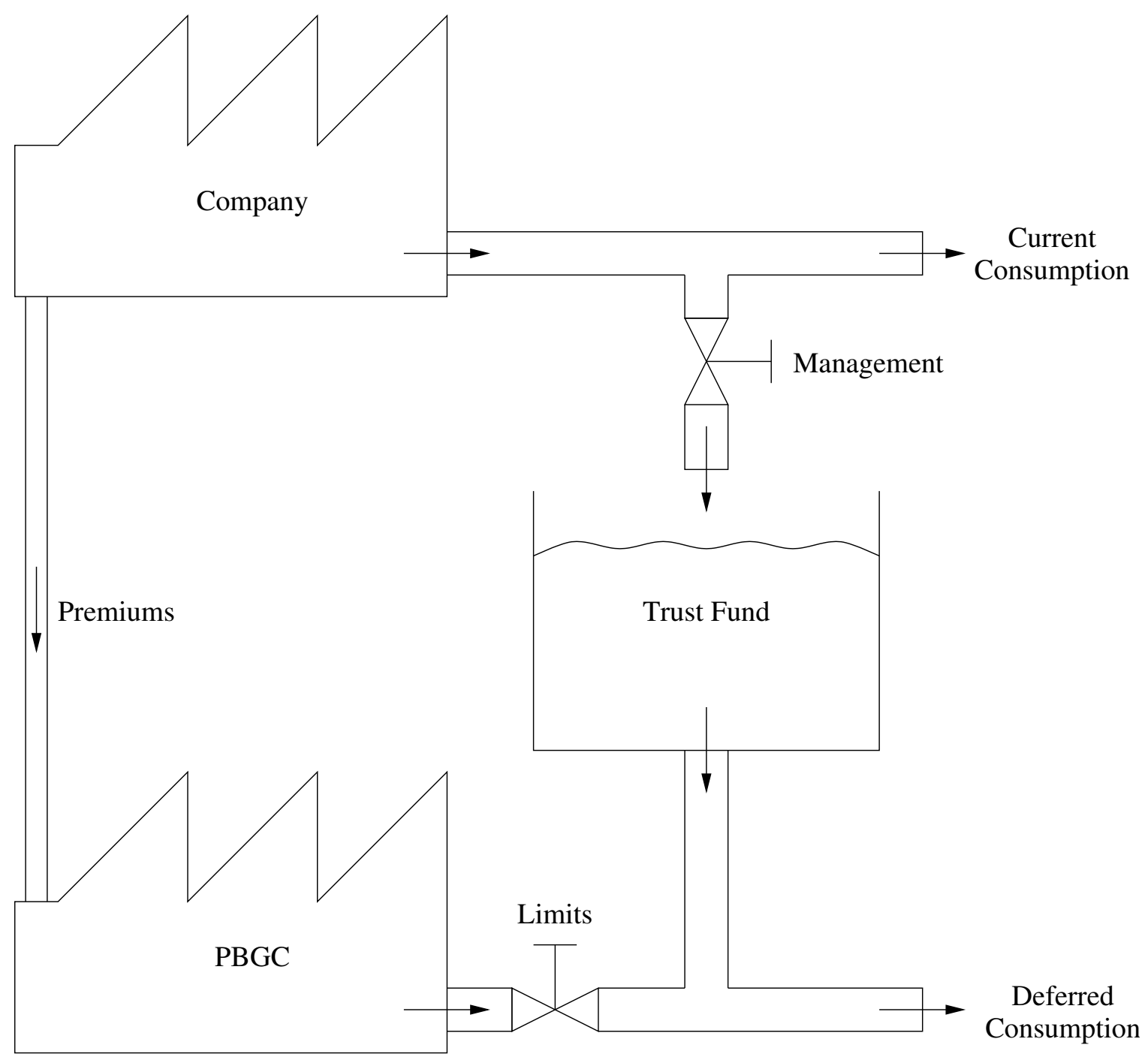

Figure 2. Analogy for a deferred compensation system with a trust find. 


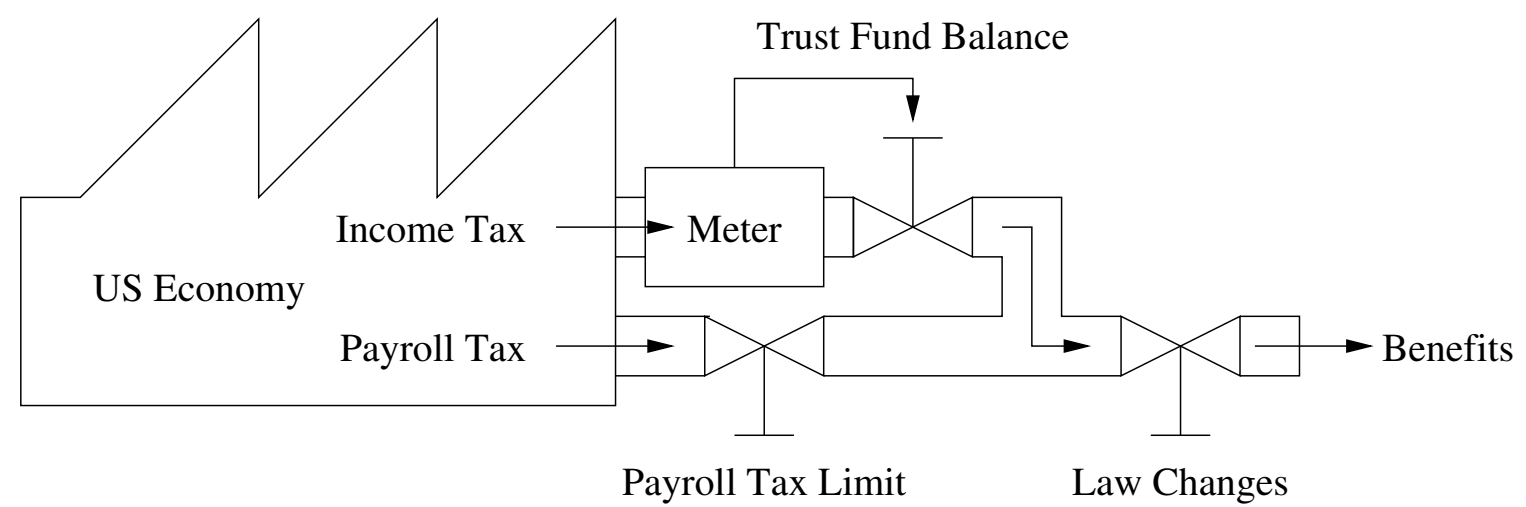

Figure 3. Analogy for the Social Security OASDI System. 